\title{
A Pattern of Physical Activity and Its Determinants in Office Workers
}

\author{
Arifah Kaharina ${ }^{1, *}$ Ratna Candra Dewi ${ }^{2,}$ Raymond Ivano Avani ${ }^{3}$ \\ ${ }^{1,2,3}$ Faculty of Sport Science, Universitas Negeri Surabaya, Surabaya, Indonesia \\ *Corresponding author. Email: arifahkaharina@unesa.ac.id
}

\begin{abstract}
The increase in non-communicable diseases can be caused by unhealthy community behavior, including low physical activity. Various benefits of physical activity include reducing the risk of degenerative diseases and depression. In addition, physical activity is the key to energy expenditure which is very important to balance energy and control body weight. There are various factors related to physical activity in office workers. This study aimed to determine the pattern of physical activity and its determinants in office workers. This study used a cross-sectional design, and the number of samples was 31 people. Height and weight data were collected using anthropometric measurement, physical activity patterns, and determinants such as demographic characteristics, sports facilities, social environment, and perceptions of physical activity collected using GPAQ. The data were analyzed using univariate analysis. The results showed that the average level of physical activity was moderate (52\%). The determinant factors that most influence physical activity participation are technological advances (transportation and communication), perceived benefits, and family support.
\end{abstract}

Keywords: Physical activity, Determinants, Office workers.

\section{INTRODUCTION}

The World Health Organization (WHO) states that physical activity is any form of body movement produced by skeletal muscles that require energy expenditure. Lack of physical activity is one of the fundamental danger factors for death from non-communicable diseases. Less active people have a $20 \%$ to $30 \%$ expanded danger of death than very busy people [1]. Regular physical activity also maintains a healthy weight and can work on psychological wellness, quality of life, and well-being. However, current global estimates show one in every four adults and $81 \%$ of adolescents are not getting sufficient active work [2].

During the last 15 years, the level of physical activity that is not sufficient has not improved, namely, in 2001, it was $28.5 \%$, while in 2016, it was still at $27.5 \%$ [1]. Indonesia also shows the proportion of lack of physical activity. In 2013 it was $26.2 \%$ and rose to $33.5 \%$ in 2018 . Lack of physical activity is a cumulative activity of fewer than 150 minutes a week [3]. It is highly recommended to carry out regular physical activity, especially during the COVID-19 pandemic. A physical activity carried out regularly and measurably can boost the immune system, increase antibody production and help remove toxins from the body [4].
Physical activity in office workers needs to be a concern, where office workers tend to sit continuously from morning to evening. Lack of movement coupled with various other factors, including smoking habits, unhealthy eating patterns, and lack of rest, can cause noncommunicable diseases. Diet and physical activity regulation in the workplace can improve the health status of workers, contribute positively and the company's caring image, improve employee morale. In addition, it reduces employee turnover, and absenteeism increases productivity and reduces sick leave [5].

Office workers spend more time just sitting in front of a screen, doing tasks until the afternoon without any particular time off to do light physical activity or stretch muscles. If it continues, it can cause health problems and reduce work performance. The workers also do not routinely carry out health checks, even to measure their nutritional status. The pattern of physical activity and what factors affect physical activity participation in office workers at the Universitas Negeri Surabaya are not yet known, so it is essential to know that to evaluate and prevent the danger of inactivity. This study aims to analyze the pattern of physical activity and its determinants in office workers. 


\section{METHODS}

This study utilized a cross-sectional design with a quantitative method approach. Subjects were selected purposively. Thirty-one workers of the Faculty of Sports Science, Universitas Negeri Surabaya, participated. Participants filled out research questionnaires in the form of anthropometric measurements and physical activity. Anthropometric data was taken by measuring the subject's height and weight. The level of physical activity was measured using the Global Physical Activity Questionnaire (GPAQ), a questionnaire created by WHO [6]. Physical activity scores were obtained from the METs-minutes/week, which was the sum of walking activity, moderate activity, and strenuous activity in duration (minutes) and frequency (days), which was then multiplied by the value of each METs [7]. The following is a BMI classification table:

Table 1. BMI Classification

\begin{tabular}{|l|c|}
\hline \multicolumn{1}{|c|}{ Classification } & BMI \\
\hline Underweight & $<18.5 \mathrm{~kg} / \mathrm{m}^{2}$ \\
\hline Ideal & $18.5-24.9 \mathrm{~kg} / \mathrm{m}^{2}$ \\
\hline Overweight & $25.0-29.9 \mathrm{~kg} / \mathrm{m}^{2}$ \\
\hline Obesity & $\geq 30 \mathrm{~kg} / \mathrm{m}^{2}$ \\
\hline
\end{tabular}

The following is a table for classifying levels of physical activity:

Table 2. Level of Physical Activity Classification

\begin{tabular}{|c|c|}
\hline Classification & Physical Activity \\
\hline High & $\begin{array}{l}\text { If it meets one of the criteria: } \\
\text { a. Three or more days of vigorous- } \\
\text { intensity activity reaching a } \\
\text { minimum of } 1500 \text { METs- } \\
\text { minutes/week, or } \\
\text { b. a combination of walking, strenuous } \\
\text { and moderate-intensity activities that } \\
\text { reach a minimum of } 3000 \text { METs- } \\
\text { minutes/week }\end{array}$ \\
\hline Moderate & $\begin{array}{l}\text { If it meets one of the criteria: } \\
\text { a. strenuous activity for three days or } \\
\text { more for } 20 \text { minutes/day, } \\
\text { b. moderate-intensity activity or } \\
\text { walking at least } 30 \text { minutes/day for } \\
\text { five days or more, or } \\
\text { c. activity strenuous intensity, } \\
\text { combined walking up to } 600 \text { METs- } \\
\text { minute/week for five days or more. }\end{array}$ \\
\hline Low & If it does not meet all of the above criteria \\
\hline
\end{tabular}

The analysis used in this research is univariate analysis. The univariate analysis provides an overview and presentation of descriptive results through the frequency and distribution of percentages.

\section{RESULTS AND DISCUSSION}

Based on measurements on the subject, the following results are obtained:
Table 3. Characteristic Subject

\begin{tabular}{|l|c|c|c|c|c|c|}
\hline \multirow{2}{*}{ Variables } & \multicolumn{4}{|c|}{$\begin{array}{c}\text { Male } \\
\text { Ne24 }\end{array}$} \\
\cline { 2 - 8 } & Min & Max & Mean \pm SD & Min & Max & Mean \pm SD \\
\hline Age & 28 & 56 & $41.54 \pm 7.81$ & 34 & 55 & $43.71 \pm 7.57$ \\
\hline Weight & 48.1 & 95.2 & $72.89 \pm 13.23$ & 56.4 & 93.6 & $73.93 \pm 16.09$ \\
\hline Height & 154 & 182 & $167.29 \pm 6.17$ & 146 & 166 & $153.57 \pm 6.93$ \\
\hline BMI & 17.9 & 33.7 & $26.10 \pm 4.15$ & 25.8 & 39.5 & $31.17 \pm 5.45$ \\
\hline
\end{tabular}

The age range of the research subjects was between 28 years to 56 years. The data on the characteristics of the subjects showed that the average BMI of male subjects was in the overweight category and the average female was in the obese category. This needs special attention because BMI is a proportion of a person's nutritional status. Nutritional status is essential in determining health status because it can describe consumption needs with nutrient intake. A healthy balance will be achieved if the amount of consumption is equivalent to the energy used. Nutritional balance is an indicator of the extent to which food, meals, or diet meet everyday necessities for all nutrients [8]. Subjects in the overweight and obese BMI categories need to reduce their daily nutritional intake and increase physical activity to achieve an ideal BMI.

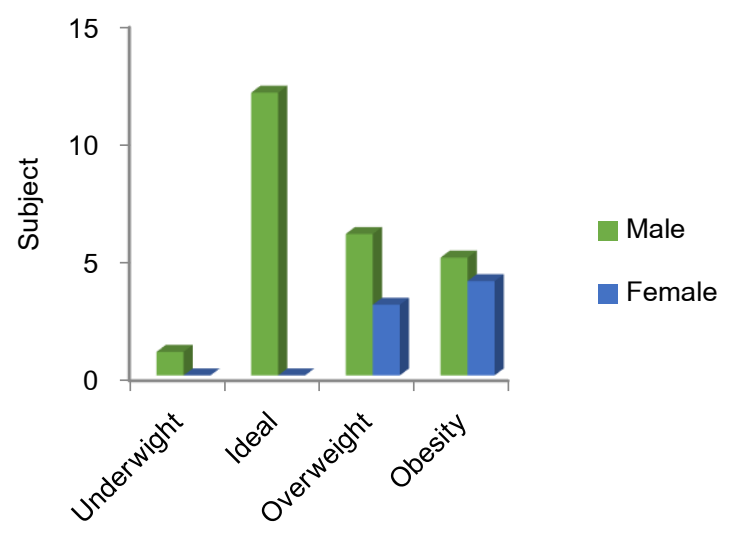

Figure 1. Subject BMI

Based on figure 1, the BMI of male subjects was mainly in the ideal category, but 11 topics were found to be overweight and obese. All-female issues belong to the sorts of overweight and obesity.

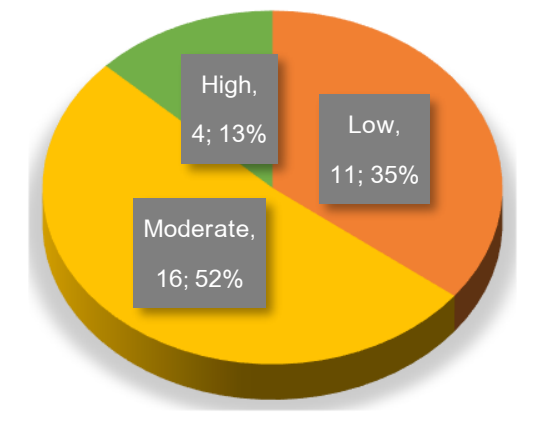

Figure 2. Subject Level of Physical Activity Note: Data were presented as n;\% 
The level of physical activity of the subjects showed quite good results, where on average the topics carried out daily physical activities in the moderate category. Still, many issues did not perform optimal physical action, indicated by 11 subjects in the low sort.

Table 4. Physical Activity Pattern

\begin{tabular}{|c|c|c|}
\hline Physical Activity & $\mathrm{N}$ & Percentage \\
\hline \multicolumn{3}{|l|}{ Sport Type: } \\
\hline Walking & 17 & $54.84 \%$ \\
\hline Running & 8 & $25.81 \%$ \\
\hline Cycling & 8 & $25.81 \%$ \\
\hline Football, Tennis, Badminton & 3 & $9.68 \%$ \\
\hline \multicolumn{3}{|l|}{ Frequency } \\
\hline$<3 \mathrm{x}$ per week & 16 & $51.61 \%$ \\
\hline$\geq 3 x$ per week & 15 & $48.39 \%$ \\
\hline \multicolumn{3}{|l|}{ Duration } \\
\hline$<30$ minutes & 9 & $29.03 \%$ \\
\hline$\geq 30$ minutes & 22 & $70.97 \%$ \\
\hline
\end{tabular}

Walking is the type of physical activity that the subject was most interested in. Sixteen subjects did physical activity more than three times per week. The duration was more than 30 minutes. It is highly recommended to stay fit during a pandemic. Adults are urged to do somewhere around 150 minutes of moderateintensity physical activity throughout the week or at least 75 minutes of vigorous-intensity physical activity [9]. Adults should build moderate-intensity physical activity to 300 minutes per week [9].

Table 5. Physical Activity Determinants

\begin{tabular}{|l|c|c|}
\hline \multicolumn{1}{|c|}{ Determinants } & $\mathrm{N}$ & Percentage \\
\hline $\begin{array}{l}\text { Technological advances } \\
\text { (transportation, telecommunications) }\end{array}$ & 31 & $100 \%$ \\
\hline Perceived Benefits & 29 & $93.55 \%$ \\
\hline Family support & 24 & $77.42 \%$ \\
\hline Availability of sports infrastructure & 21 & $67.74 \%$ \\
\hline Perceived Barriers & 7 & $22.58 \%$ \\
\hline $\begin{array}{l}\text { Work environment support } \\
\text { (coworkers) }\end{array}$ & 6 & $19.35 \%$ \\
\hline Medical history & 2 & $6.45 \%$ \\
\hline
\end{tabular}

The determinant factor that most influences the subject's physical activity participation is technological advances. The ease of technology in the field of transportation and communication makes people lazy to do physical activity. All topics chose to use motorized transportation, such as motorcycles and cars. Technological advances are considered to be the main factor in the subject's behavior becoming inactive. As nations develop economically, levels of inactivity increment and can be as high as $70 \%$ because of changing transport patterns, increased use of technology for work and recreation, cultural values, and expanding inactive practices [2].
Perceived benefits are other factors that affect participation in physical activity. Adults who have a positive perception of the benefits of physical activity (perceived benefits), such as preventing disease, getting an ideal body shape, or relieving stress, tend to do more physical activity than those who do not have a positive perception. On the other hand, adults who have a high negative perception of barriers to physical activity (perceived barriers) are less likely to engage in physical activity [10].

Family support is a factor that is exceptionally influential on the participation of the subject's physical activity. Social support from family can build selfviability convictions and participation in physical activity [11]. Environmental factors positively influence physical activity through intermediary social support and exercise self-efficacy [12].

Subjects consider the availability of sports facilities as an essential factor to be a concern in carrying out physical activity. Accessibility of sports facilities showed a significant relationship with participation in physical activity[13]. So it is crucial to consider the completeness of sports facilities by establishing a conducive environment for physical activity or designing programs to increase physical activity [13].

Efforts to maintain health by staying active and maintaining a healthy diet for office workers have been recommended. WHO and the World Economic Forum have campaigned for a Workplace Health Promotion program that targets physical activity and diet to be effective in: (1) Changing lifestyle behaviors - such as increasing physical activity and eating habits; (2) Improving health-related outcomes - such as reduced body mass index (BMI), reduced blood pressure and other cardiovascular disease risk factors; (3) Facilitating organizational-level change - such as reducing absenteeism [5].

\section{CONCLUSION}

The results showed that the average level of physical activity was moderate. Types of exercise such as walking, running, and cycling. Determinant factors that affect physical activity participation at most technological progress (transportation and communication), perceived benefits, and family support. The results of this study can be used as input and consideration in preparing a health promotion program that supports increasing the physical activity of office workers in the Universitas Negeri Surabaya campus. 


\section{AUTHORS' CONTRIBUTIONS}

All authors planned and performed the research, discussed the outcomes, and contributed to the final manuscript.

\section{ACKNOWLEDGMENTS}

This research was upheld by research grants from the Faculty of Sports Science, Universitas Negeri Surabaya.

\section{REFERENCES}

[1] World Health Organization. Physical Activity. Published 2020. https://www.who.int/newsroom/fact-sheets/detail/physical-activity

[2] Delgado-Gonzalo R, Renevey P, Lemkaddem A, et al. Physical activity. Seamless Healthcare Monitoring: Advancements in Wearable, Attachable, and Invisible Devices. doi:10.1007/978-3-319-69362-0_14

[3] Kementerian Kesehatan Republik Indonesia. Hasil Utama RISKESDAS 2018.; 2018. https://kesmas.kemkes.go.id/assets/upload/dir_519 d41d8cd98f00/files/Hasil-riskesdas2018_1274.pdf

[4] Kementerian Kesehatan Republik Indonesia. Panduan Gizi Seimbang Pada Masa Pandemi Covid-19 “Lindungi Keluarga.”; 2020.

[5] World Health Organization \& World Economic Forum. Preventing non-communicable diseases in the workplace through diet and physical activity: WHO/World Economic Forum report of a joint event.; 2008. https://apps.who.int/iris/handle/10665/43825

[6] Global Physical Activity Questionnaire Analysis Guide GPAQ Analysis Guide Global Physical Activity Questionnaire (GPAQ) Analysis Guide. Published online 2002. http://www.who.int/chp/steps/GPAQ/en/index.htm 1
[7] Fogelholm M, Malmberg J, Suni J, et al. International Physical Activity Questionnaire. Medicine \& Science in Sports \& Exercise. doi:10.1249/01.mss.0000194075.16960.20

[8] Fern EB, Watzke H, Barclay D V., Roulin A, Drewnowski A. The nutrient balance concept: A new quality metric for composite meals and diets. PLoS One. 2015;10(7):e0130491. doi:10.1371/journal.pone.0130491

[9] World Health Organization. \#HealthyAtHome Physical activity. Campaigns. Published 2020. https://www.who.int/news-

room/campaigns/connecting-the-world-to-combatcoronavirus/healthyathome/healthyathome--physicalactivity?gclid=Cj0KCQjw5PGFBhC2ARIsAIFIM NdxNoYz2zasLQKvygBoNblTPIVR2GFQrWjsM U60dheYjpPA0TXk_egaAlaMEALw_wcB\%0Aht tps://www.who.int/new

[10] Ibrahim S, Karim NA, Oon NL, Ngah WZW. Perceived physical activity barriers related to body weight status and sociodemographic factors among Malaysian men in Klang Valley. BMC Public Health. 2013;13(1):1-10. doi:10.1186/1471-2458$13-275$

[11] Theodoropoulou E, Stavrou NAM, Karteroliotis K. Neighborhood environment, physical activity, and quality of life in adults: Intermediary effects of personal and psychosocial factors. J Sport Heal Sci. 2017;6(1):96-102. doi:10.1016/j.jshs.2016.01.021

[12] Ishii K, Shibata A, Oka K. Environmental, psychological, and social influences on physical activity among Japanese adults: Structural equation modeling analysis. Int J Behav Nutr Phys Act. 2010;7(1):1-8. doi:10.1186/1479-5868-7-61

[13] Lee SA, Ju YJ, Lee JE, et al. The relationship between sports facility accessibility and physical activity among Korean adults. BMC Public Health. 2016;16(1). doi:10.1186/s12889-016-3574-Z 